\title{
CLARICE LISPECTOR, HÉLÈNE CIXOUS, E A MIOPIA COMO PROCEDIMENTO ${ }^{1}$
}

\author{
Flavia Trocoli ${ }^{2}$ \\ Universidade Federal do Rio de Janeiro - UFRJ, Brasil
}

\begin{abstract}
Resumo
Este artigo propõe-se a mostrar como Hélène Cixous lendo Clarice Lispector refabricou um modo de ler pelo detalhe. Seu trabalho sobre as obras claricianas procede através de uma atenção microscópica ao detalhe. O método de leitura é apreendido através do exame e da reinvenção do detalhe que transita entre uma obra e outra, em passagem e em metamorfose. Jacques Derrida mostra que um texto pode herdar a lei de outro texto sem sequer referir-se a ele explicitamente, e é esta a relação que, através da transposição recriadora de certas palavras - o saber, o ver, a miopia, a cegueira, a instabilidade na relação com o outro e com o mundo, tentarei apreender entre o conto clariciano, "Evolução de uma miopia", de 1964, e o ensaio poético cixouniano, "Savoir"/ "Saber ver", de 1998.
\end{abstract}

Palavras-chave: Clarice Lispector; Hélène Cixous; Ato de releitura; Método.

\begin{abstract}
This paper aims to show how Hélène Cixous, by reading Clarice Lispector, recreates a way of reading through the detail. The author's works on Clarice's writings operates through a microscopic attention to details. The reading method is understood through the exam and reinvention of the detail that moves throughout the works, passing through them, in a process of metamorphosis. Jacques Derrida shows that a text can inherit the law of another text, even without referring to it explicitly, and, it is this relation, through the reinvented transposition of certain words - the knowledge, the see, the myopia, the blindness, the instability in the relation with the other and with the world, that I will try to apprehend in "Evolution of a myopia", Clarice's short story, from 1964, and Cixous's poetic essay "Savoir", from 1998.
\end{abstract}

Keywords: Clarice Lispector; Hélène Cixous; Method; Rereading act. 


\section{aceitara a incerteza, e lidava com os componentes da incerteza com a concentração de quem examina através das lentes de um microscópio. \\ Clarice Lispector, em "Evolução de uma miopia" Eu te chamo para o fino trabalho do sonho: passar o invisivel bisturi a laser primeiro entre as letras ${ }^{3}$ Hélène Cixous, em Rêve je te dis}

Se para este Dossiê “o que está em causa é problematizar o suposto divórcio entre a trama da escrita e o conteúdo que ela veicula", as linhas traçadas doravante pretendem mostrar os laços fortes, e nem sempre visíveis, que atam duas escritas em seus procedimentos, colocando em primeiro plano a dificuldade de que, diante de uma obra literária, procedimentos e métodos de leitura nunca estão prontos e precisam ser problematizados e reinventados a cada leitura. $O$ Grande Dicionário Houaiss nos deixa saber que, etimologicamente, "proceder" ata-se a aparecer, a nascer, a acontecer e a ceder, palavras caras às autoras em questão neste artigo. Nele, tentarei mostrar como Hélène Cixous lendo Clarice Lispector refabricou um modo de ler pelo detalhe, sendo que refabricar também é uma palavra fundamental para este artigo, como mostrarei adiante ${ }^{4}$. Sua leitura das obras procede através de uma atenção microscópica ao detalhe e à porosidade. O método é apreendido através do detalhe que transita entre uma obra e outra, em passagem e em metamorfose; perseguindo essa difícil apreensão do detalhe em movimento, permito-me tanto lembrar que o narrador de Em busca do tempo perdido, em suas primeiras páginas, diz que o "edifício imenso da recordação", sobre ruínas, é suportado por uma "gotícula impalpável", quanto citar um fragmento de uma crônica de Clarice Lispector:

E de repente aquela dor intolerável no olho esquerdo, este lacrimejando, e o mundo se tornando turvo. E torto, o outro automaticamente se entrefecha. Quantas vezes no decorrer de menos de um ano um objeto estranho agrediu meu olho esquerdo: duas vezes ciscos não identificados, uma vez um grão de areia, outra um cílio. Das quatro vezes tive que procurar um oftalmologista de plantão. Da última vez perguntei àquele que realiza sua vocação através de cuidar por assim dizer da nossa visão do mundo, por que sempre o olho esquerdo? É simples coincidência?

Ele respondeu que não. Que por mais normal que seja uma vista, um dos olhos vê mais que o outro e por isso é mais sensível, prende o corpo estranho, não o expulsa (Lispector, 1999, p. 478).

Como veremos adiante Hélène Cixous, em ensaio publicado na edição comemorativa dos quarenta anos de A hora da estrela, 1977, com o título "Extrema fidelidade"6, insiste na metáfora segundo a qual Macabéa seria um cisco que provocou um mar de lágrimas no autor. Neste artigo, não começarei pela obra de adeus de Clarice Lispector, mas escreverei sobre o meu encontro com "Savoir" (que Fernanda Bernardo traduziu por "Saber ver", 2001), 1998, de Hélène Cixous e a releitura que ele provocou de "Evolução de uma miopia", nono conto 
de A legião estrangeira, 1964, que reúne contos muito célebres de Lispector: o livro começa com "Os desastres de Sofia”, termina com "A Legião Estrangeira” e em seu quase meio está cravado "O ovo e a galinha”. Não por acaso, são três narrativas em primeira pessoa, ao passo que a maioria das outras dez apresenta um narrador distante, não participante da cena narrativa. Não por acaso, essas três narrativas lançam fios que enlaçam as outras: a infância e o nascimento do desejo, as cenas do olhar e a recusa à evidência como consenso, a morte. Em sua força inequívoca e em seu prestígio crítico, o modo como esses contos célebres se destacam acabam deixando as outras dez narrativas à sombra, como se fossem pontos cegos no esplendor dos contos consagrados.

Dito esse efeito de apagamento causado pela celebridade de três contos, proponho-me a lançar alguma luz à "Evolução de uma miopia", ele começa assim:

Se era inteligente, não sabia. Ser ou não inteligente dependia da instabilidade dos outros. Às vezes o que ele dizia despertava de repente nos adultos um olhar satisfeito e astuto. (p.91) [...] Que a sua própria chave não estava com ele [...] É que a chave não estava com ninguém, isso ele foi aos poucos adivinhando sem nenhuma desilusão, sua tranquila miopia exigindo lentes cada vez mais fortes." (Lispector, 1992, p.92).

Essas primeiras linhas condensam muitas questões que atravessam o conto, o próprio livro e atravessará, como veremos adiante, "Savoir"/ "Saber ver": o saber, o ver, a miopia, a cegueira, a instabilidade na relação com o Outro e com o mundo. Essas questões entram em ressonância com aquelas que abrem o livro, no primeiro conto, "Os desastres de Sofia", uma menina chamada Sofia, diante da tarefa de escrever uma composição, subverte o sentido da história e perturba o olhar do professor. A história contada pelo professor é a seguinte: um homem muito pobre sonhara que descobrira um tesouro e ficara muito rico. Depois do sonho, andara o mundo procurando e voltara para sua casinha e sem ter o que comer começa a plantar no seu próprio quintal. Tanto plantara, tanto colhera, que acabara ficando rico. A menina, então, em sua composição, conclui pela moral oposta: o trabalho árduo não é o único meio de se chegar aos tesouros, há tesouros que esperam para serem apenas descobertos, em sujos quintais. É o ideal do trabalho árduo que engrandece (e liberta) que cai na poeira dos quintais.

Já no último conto, "A legião estrangeira", uma menina chamada Ofélia é arrebatada por um pintinho comprado na feira por sua vizinha, a narradora. Às escondidas do olhar da narradora, Ofélia deseja e mata o pintinho. Antes do encontro com o pintinho, era uma menina que vivia como adulta, vigilante de lugares comuns que se tornam verdadeiros imperativos sob o olhar da narradora. Depois do pintinho, Ofélia perde sua armadura de sentidos prontos e se torna uma criança que escapa às adequações da vida adulta, com isso entra em conformidade com o que tem: a própria infância. Em "Extrema fidelidade", Hélène Cixous pinça este estar em conformidade com o que se tem e insiste nele: "Há toda uma série de textos que trabalham sobre a questão do ter, de saber ter o que se tem. Esta é uma das coisas mais difíceis do mundo, porque, pobres humanos que somos, nem bem temos, já não temos" (Cixous, 2017, p. 146) (Negrito de H.C.). 
Se em "Os desastres de Sofia" e em "A legião estrangeira", as narradoras estão diretamente implicadas na narrativa e na narração, no enunciado e na enunciação, vendo ao mesmo tempo de muito perto e de longe, em "Evolução de uma miopia", o narrador está à distância, é responsável pela narração, mas está fora da narrativa, ele não participa da cena. Tentarei pensar as implicações desses modos de formalização do ponto de vista e da cegueira. Se em "A Legião Estrangeira", a narradora testemunha aturdida o nascimento de Ofélia para um complexo desejo infantil que mistura desejo e destruição, o narrador de "Evolução de uma miopia" parece já ter elaborado o crescimento do menino, crescimento que implica um saber-fazer com aquilo que é passageiro e variável no tempo e no Outro. Um menino sem nome descobre um impossível do amor, quando se vê transportado do ver-se idealizadamente no olho do Outro para o ponto cego no Outro. Cito:

[...] no começo de sua miopia, ele se indagava por que uma vez conseguia mover a família, e outra vez não. Sua inteligência era julgada pela falta de disciplina alheia?

Mais tarde, quando substituiu a instabilidade dos outros pela própria, entrou num estado de instabilidade consciente. Quando homem, manteve o hábito de pestanejar de repente ao próprio pensamento, ao mesmo tempo que franzia o nariz, o que deslocava os óculos - exprimindo com esse cacoete uma tentativa de substituir o julgamento alheio pelo próprio, numa tentativa de aprofundar a própria perplexidade, sem que ela se transformasse em outro sentimento.

[Que] a sua própria chave não estava com ele. [...] É que a chave não estava com ninguém (Lispector, 1992, p.92).

Nota-se o movimento implacável da narração: após indicar uma tentativa de substituir o julgamento alheio pelo próprio, há um corte triplo através do ponto final, da abertura de novo parágrafo e do próprio pronome "Que". Em três tempos, esse corte consuma certos deslocamentos: do alheio ao próprio e do próprio ao de ninguém. Isso posto, o leitor poderá retroagir ao começo do conto "Ser ou não inteligente dependia da instabilidade dos outros." (Lispector, 1992, p.91) e pensar que essa primeira parte do conto é uma argumentação que sustenta essa afirmativa inicial; e, até este ponto, é como se estivéssemos diante de um ensaio filosófico. Nota-se também que, se na peça de Shakespeare aludida é o atormentado e hesitante Hamlet quem enuncia o seu ser ou não ser, no conto de Clarice, é o narrador que, a sangue frio, coloca em cena a questão do ser atada a uma certa distância própria à inteligência, na primeira linha do conto já se leu - "Ser ou não inteligente". Embora, claro, em outros momentos da peça shakespeariana não falte a Hamlet a ironia que não deixa de ser um modo de distância inteligente.

A argumentação calma e filosófica do próprio narrador, feita no parágrafo mais longo do conto, é interrompida pela notícia de que, dentro de uma semana, o menino passaria um dia inteiro na casa de uma prima. Neste ponto, o narrador passa a acompanhar as "tergiversações" do menino através das seguintes formulações: "começou por tentar decidir", "procurava decidir", "ou se faria algo que julgasse", "Ter a possibilidade de escolher o que seria", "o círculo de possibilidades foi se alargando". Nessas expressões, vigora, conforme 
aos ardis da razão, todo um esforço de conceber-se em conciliação com o olhar do Outro, em satisfazê-lo. Em seguida, o menino abandona todas essas cogitações para imaginar o que faria na casa da prima: "E finalmente entrou no campo da prima propriamente dita. De que modo deveria encarar o amor que a prima tinha por ele?" (Lispector, 1992, p.95) Corte e começo de um novo parágrafo. "No entanto, negligenciara um detalhe: a prima tinha um dente de ouro, do lado esquerdo." Corte e novo parágrafo. "E foi isso - ao finalmente entrar na casa da prima - foi isso que num só instante desequilibrou toda sua construção antecipada" (Idem). Ao contrário do que o menino imagina, o suposto amor da prima não aparece de forma evidente, como lemos nestas linhas: "Ela foi logo dizendo que ia arrumar a casa e que ele podia ir brincando. O que deu ao menino, assim de chofre, um dia inteiro vazio e cheio de sol" (Lispector, 1992, p.96).

Um dente de ouro e uma ausência de atenção mudam o ritmo do conto acentuando a instabilidade: "um safanão de liberdade" através do qual "por um dia inteiro ele não seria nada" (Idem). Neste ponto, o leitor poderia espantar-se e perguntar-se pela causa do desabamento: um dente de ouro ou uma ausência de olhar? Os dois causam o desabamento da certeza antecipada: um ver (um dente) e um não ser visto (pela prima); os dois detalhes são "invisos"7 e inesperados.

E o leitor não demora a deparar-se com um terceiro movimento desestabilizador: a apresentação da "pressão de delicada do amor da prima", que avança como a tarde. Se alguns parágrafos antes, o narrador localizava a entrada do menino no terreno propriamente da prima, é somente nesses parágrafos finais que se dá a ver o cerne do dilema do ser ou não ser atado ao dilema do ver ou não ver. No primeiro parágrafo, o dilema aparece em torno do ser ou não inteligente, nos parágrafos finais aparece em torno de ser ou não amado: "era um amor pedindo realização, pois faltava à prima a gravidez, que já é em si um amor materno realizado. Mas era um amor sem a prévia gravidez. Era um amor pedindo, a posteriori, a concepção. Enfim, o amor impossível. (Lispector, 1992, p.96)

Se falta à prima a concepção, é isso que, de certo modo, também falta ao conto. Numa volta sobre ele mesmo, pode-se dizer que nada é concebido propriamente dito: as ideias e os ideais estão todos em estado de desaparecimento não de forma abstrata ou reflexiva, mas de forma bem concreta eles são escritos provisoriamente. O leitor pode construir a hipótese de que a própria leitura é uma travessia da concepção que passa não somente pelo conceitual, mas também pelo ideal, até chegar a uma ação que pode ser constituída também como crítica ao ideal. Tal travessia inclui, e não expulsa, o ponto cego do menino que converge com o ponto cego da prima, e ambos convergem com a narrativa como ponto cego porque pôs a perder o já concebido, o já visto. No fim, lê-se:

O relance mais profundo e simples que teve da espécie de universo em que vivia e onde viveria. Não um relance de pensamento. Foi apenas como se ele tivesse tirado os óculos, e a miopia mesmo que o fizesse enxergar. Talvez tenha sido a partir de então que pegou um hábito para o resto da vida: cada vez que a confusão aumentava e ele enxergava pouco, tirava os óculos sob o pretexto de limpá-lo e, 
sem óculos, fitava o interlocutor com uma fixidez reverberada de cego (Lispector, 1992, p.97).

No fim, a própria construção desaba, não é um relance de pensamento, é um relance no corpo que faz com que a narração se debruce sobre o universo de uma pequena ação: a de tirar os óculos para não enxergar de longe. E é o próprio narrador o ponto cego da narrativa, não estando nela, de longe, é ele que delineia as tergiversações do menino e também o ponto em que todas elas sofrem a ação do bisturi: um dente, uma retirada do olhar, um amor impossível - o de ser filho para aquela que não o concebeu. Vou me deter nesses três pontos cortantes.

O primeiro ponto cortante concretiza-se em um dente de ouro, um elemento, que é estranho à lógica causal ou àquilo que ainda se poderia chamar de enredo ou de trama. É um elemento material que interrompe uma construção e que, mesmo depois, não é assimilado por ela ou pelo próprio capricho da inteligência do menino. Trazido à situação narrativa, ele quebra qualquer consenso anterior ou posterior e, assim, "põe de luto o saber da noite passada" (Cixous, H. e Derrida, J., 2001) ${ }^{8}$. Em outras palavras, a inteligência não é do menino, nem propriamente do narrador, mas da própria evolução da narração que, de corte em corte, faz evoluir a miopia, sobrepondo pontos cegos, examinando nuances fugidias, e colocando concepções e visões do menino em xeque. O segundo ponto cortante pode ser localizado como uma retirada do olhar como uma recusa ao ser. Recusando-se a ser o filho não concebido da prima, o menino mantém à distância o olhar que o objetifica, mantém o movimento difícil de proximidade e distância do olhar do Outro. Finalmente, o terceiro ponto cortante pode ser pensando como uma evolução que recusa um "amor pedindo realização", pedindo a posteriori a concepção, para o aprendizado da ação de tirar os óculos. Para contrastar, retomo mais uma vez a evolução das últimas linhas:

Nesse dia, pois, ele conheceu uma das raras formas de estabilidade: a estabilidade do desejo irrealizável. A estabilidade do ideal inatingível. Pela primeira vez, ele, que era um ser votado à moderação pela primeira vez sentiu-se atraído pelo imoderado: atração pelo extremo impossível. E pela primeira vez teve então amor pela paixão.

E foi como se a miopia parasse e ele visse claramente o mundo. O relance mais profundo que teve da espécie de universo que em que vivia e onde viveria. Não um relance de pensamento. Foi apenas como se ele tivesse tirado os óculos, e a miopia mesmo é que o fizesse enxergar. Talvez tenha sido a partir de então que pegou um hábito para o resto da vida: cada vez que a confusão aumentava e ele enxergava pouco, tirava os olhos sob o pretexto de limpá-los e, sem óculos, fitava o interlocutor com uma fixidez reverberada de cego (Lispector, 1992, pp.96-97).

Muito se poderia especular em torno das concepções em torno do amor e da paixão, em torno do ideal e do impossível, mas gostaria de chamar a atenção para a frase "Não um relance de pensamento", pois é ela que me permite pensar que, sim, há uma vigência de certa mensagem no conto em torno do ser ou não-ser inteligente, o que o narrador chama de 
tergiversação, que é também arrumar desculpa, mas, sobretudo, há relances na narração que interrompem o pensamento, a concepção. Assim, evoluir pode ser justamente o movimento de passagem da ideia que tergiversa para a ação que, no só-depois da releitura, sustenta o título e a própria composição, inscrevendo-se nela como ação da personagem e do narrador, ação que, como "um invisível bisturi a laser entre as letras" não deixa nenhuma soberania ao consenso, e nem à visão que abstrai o mendigo na porta do cinema transformando-o e fixando-o em ideia.

Remeto-me àquilo que, em A legião estrangeira, está no meio da composição a se desnudar das concepções, isto é, o ovo: "Então - livre, delicado, sem mensagem alguma para mim - talvez uma vez ainda ele se locomova do espaço até esta janela que desde sempre deixei aberta. E de madrugada baixe no nosso edifício. Sereno até a cozinha. Iluminando-a de minha palidez" (Lispector, 1992, p.66). Afinal, talvez seja no momento em que se reconhece que Clarice não deixou nenhuma mensagem já pronta para nós, é que possamos recomeçar a reler sua obra, empalidecendo o eu que vê para fazer justiça ao objeto ainda não visto, isto é, deixando em segundo plano as mensagens moderadas do enunciado para deixar vir à tona os procedimentos extremos da enunciação.

Foi Jacques Derrida, aquele que colocou seu corpo e o drama da escrita da cena enunciativa na cena filosófica, quem disse que um texto pode herdar a lei de outro texto sem sequer referir-se a ele explicitamente, é esta a relação que tentarei apreender entre a miopia do conto clariciano e a miopia do ensaio poético cixouniano. Para Hélène Cixous, a escrita vem de longe - do mais estrangeiro dos estrangeiros - e vai justamente para onde o eu não quer ir. Em Voiles/Véus... à vela, obra que contém dois escritos autobiográficos, um de Hélène Cixous e outro de Jacques Derrida, o leitor clariciano talvez possa ler a contraluz e no detalhe o conto "Evolução de uma miopia". Saber, ver, miopia, amor, são palavras que são transportadas do conto de Lispector para o escrito de Cixous para fazer a travessia do invisível através do escrito 9 . De um menino a uma mulher, de uma miopia a ser conquista a outra a ser perdida, de um corpo ao outro, é a partir da diferença sexual que se escreve "Savoir/Saber ver", sob um véu um corpo feminino - "esta mulher", a que confessa os efeitos de uma cirurgia de miopia - a passagem do não ver e não ser vista para ver de um golpe, sem as lentes de contato, ver a olho nu. Cito primeiramente o não ver na tradução de Fernanda Bernardo:

A miopia era sua falta, a sua trela, o seu imperceptível véu natal. Coisa estranha, ela via que não via, mas não via bem. Em cada dia havia recusa, mas quem poderia dizer de onde vinha a recusa: e quem se recusava, o mundo ou ela? Ela era desta raça obscura subreptícia que caminha desamparada diante do grande quadro do mundo, todo o dia em pose de confissão: não vejo o nome da rua, não vejo o rosto, não vejo a porta, não vejo vir e sou eu que não vejo o que deveria ver. Tinhas olhos e era cega. [...] Como sabe o povo dos míopes, a miopia tem o seu assento vacilante no juízo. Faz reinar uma eterna incerteza que nenhuma prótese dissipa (Cixous, 2001, p.9). ${ }^{10}$ 
O menino do conto clariciano faz um caminho de conquista de sua miopia, isto é, uma desconstrução e uma reconstrução para poder recusar-se aos juízos prontos, facilmente reproduzidos, do mundo e passar ao benefício da incerteza. Aquela que escreve no fragmento acima diz de sua pertença prévia ao povo dos míopes, talvez aludindo à sua filiação clariciana. Logo, o ponto-de-chegada do menino sem nome torna-se o ponto-de-partida da mulher sem nome, mas lá e cá, a miopia é um véu que vela a visão total (como no parágrafo final do conto) e, no poema em prosa de Cixous, de "falta", a miopia passará a ser objeto de um trabalho de luto. Trabalho de luto que se faz com outra literatura. Para fazer seu luto, uma judia franco-argelina, cuja língua materna é o alemão, encontra a voz estranha e familiar de um judia nordestina expulsa da Ucrânia ainda bebê. Um encontro que Cixous escreverá nos poros da pele de seu texto.

À maneira de "Os desastres de Sofia", a miopia cixouniana subverte a relação entre a falta e o tesouro. É como se aquela que foi objeto da cirurgia precisasse fazer o luto não só de um traço de identificação, mas da mascarada, da verdade e do próprio destino:

[...] a ciência acabava de vencer o invencível. Tudo se consumou em dez minutos. Fim do infinito. Uma possibilidade ainda impossível há três anos atrás. [...] Nunca lhe tinha passado pela cabeça que um dia poderia vir a mudar o destino. O sangue, uma vez derramado na poeira, não volta mais às veias. Nunca ninguém teria contradito Ésquilo. Eis que o sangue voltou. Ela renasceu. [...] Antes ela não era uma mulher, era em primeiro lugar uma míope quer dizer uma mascarada. [...] A miopia era a sua verdade (Cixous, 2001, pp. 12-14). ${ }^{11}$

As frases são notáveis naquilo que elas condensam: as questões entre finitude e infinitude, entre possibilidade e impossibilidade, entre mascarada e verdade. No entanto, essas questões filosóficas e psicanalíticas aparecem através da experiência concreta de uma mulher, uma experiência sofrida no próprio corpo e que transforma a relação do sujeito com o mundo, assim como o gesto final do menino de "Evolução de uma miopia", de retirar os óculos, transforma a relação dele com o olhar dos outros e consigo mesmo. Mas, não só a filosofia e a psicanálise aparecem metamorfoseadas pela cena da confissão poética, como também a tragédia de Ésquilo, numa espécie de reversão, ela mesma trágica: aquilo que nas Eumênides aparece como destino incontornável, em "Savoir"/ "Saber ver" aparece tragicamente como reversibilidade do irreversível, o sangue derramado na poeira volta a correr nas veias. É um detalhe com o qual não se contava - trágico $^{12}$ - que desequilibra ou faz desmoronar a construção antecipada, como o dente de ouro da prima em "Evolução de uma miopia".

Passemos pelo detalhe em outro momento da obra de Cixous. Em Manhattan: lettres de la préhistoire/Manhattan: cartas da pré-história, de 2002, a narradora põe-se a fazer um pequeno inventário de detalhes da sua história e da própria literatura: o lenço de Otelo, um quadro no quarto de Gregor Samsa, de A metamorfose, a lanterna mágica no quarto de Marcel, em No caminho de Swann. Mais adiante, ela nos dá mais pistas sobre o modo de compor de sua literatura: 
J'ouvre un livre, la lumière est, la langue commence aussitôt son récit, je me refabrique toujours moi-même avec ces molécules littéraires me disais-je autrefois comme aujourd'hui, Il est six heures du matin sept heures parfois, j'entends le souffle régulier et curieusement fort des livres sur mes étagères (Cixous, 2002, p.77). ${ }^{13}$

Pode-se dizer que essas moléculas literárias não refabricam apenas a narradora, mas também a estrutura narrativa que recebe seu sopro. Se Jacques Derrida pode dizer que há em cada obra uma "gênese da literatura"14 é porque não só há um enunciado em Manhattan que diz "me refabrico com moléculas literárias", remetendo ao $E u$ da narradora, mas também porque tal enunciado remete ao princípio de fabricação do próprio livro e às línguas faladas pela narrativa do livro. Refabrica-se, ao mesmo tempo, o $E u$ e a Literatura, um $E u$ de Literatura, mas não uma Literatura do $e u$ no sentido estritamente autobiográfico. As obras de Cixous podem ser pensadas como sobreposições de moléculas que são roubadas da Literatura, da História, da Desconstrução, da Psicanálise. E tal roubo não se passa no plano simplesmente temático ou do enunciado, mas da própria estrutura da enunciação. ${ }^{15}$

Em $O$ riso da medusa, 1975, Hélène Cixous apontou a impossibilidade de definição de uma prática feminina da escrita, o que não quer dizer que ela não exista. Sua existência é atravessada tanto por um privilégio da voz, com ênfase no ritmo e no canto, que desregula o andamento linear da escrita, quanto pela indecidibilidade do verbo "voler" que, em francês, significa, intransitivamente, voar, e, transitivamente, roubar. O que $O$ riso da medusa não enfatiza é este apelo ao detalhe. No entanto, em "Extrema fidelidade", a leitura crítica, não ficcional, empreendida da obra de Clarice Lispector é também ditada pelo pequeno, pelo mínimo, pelo mais insignificante. De "Extrema fidelidade", recolho algumas formulações:

* No dia seguinte o autor será uma estrela entre estrelas, molécula entre todas as moléculas (Cixous, 2017, p.131).

* Essa coisa ínfima, vista de perto, mostrava-se uma criatura humana, minúscula, que pesava trinta quilos (Idem, p.132).

* Conta minusculamente, fragmentariamente. Macabéa não é (senão) uma personagem de ficção. É um grão de poeira que entrou no olho do autor e provocou um mar de lágrimas (Ibidem).

* É de tal modo mínima, de tal modo ínfima, que está ao rés do ser, [...] ela é atenta e nos faz atentos às insignificâncias que são nossas riquezas essenciais (Idem, p.134).

Gostaria que tais formulações "Extrema fidelidade" fossem a ponte entre os traços que, em $O$ riso da medusa, Hélène Cixous alinha ao lado de uma escrita feminina, traços que não lhe dão substância, mas operam nessa escrita, e aquilo que Gilda de Mello e Souza formula em "O vertiginoso relance" a partir de sua leitura de A maçã no escuro, 1964, de Clarice Lispector. A meu ver, as linhas que citarei estão entre as mais elucidativas do fazer de Clarice e do fazer de Hélène, seja ele ficcional ou crítico (no caso de Cixous), assim começa o ensaio de Gilda de Mello e Souza: 
Não será difícil apontar na literatura feminina a vocação da minúcia, o apego ao detalhe sensível na transcrição do real, características que, segundo Simone de Beauvoir, derivam da posição social da mulher. Ligada aos objetos e deles dependendo, presa ao tempo, em cujo ritmo se sabe fisiologicamente inscrita, a mulher desenvolve um temperamento concreto e terreno, movendo-se como coisa num universo de coisas, como fração de tempo num universo temporal. [...] Assim, o universo feminino é um universo de lembrança ou de espera, tudo vivendo não de um sentido imanente, mas de um valor atribuído. [...] a mulher procura sentido no espaço confinado em que a vida se encerra: o quarto com os objetos, o jardim com as flores, o passeio curto que se dá até o rio ou a cerca. A visão que constrói é por isso uma visão de míope, e o terreno que o olhar baixo abrange, as coisas muito próximas adquirem uma luminosa nitidez de contornos. (Mello e Souza, 2009, p. 97).

Em outro trabalho, seria preciso distinguir e contextualizar as diferentes leituras de Beauvoir e de Cixous em torno do feminino e do feminismo; neste artigo, contudo, é importante destacar o traço compartilhado da miopia e daquilo que nela se desdobrou e ainda se desdobra. É inegável que as mulheres estejam ampliando sua participação no mundo, transformando sua posição social e é conhecida a atuação excepcional de Hélène Cixous na cena intelectual francesa. Como também é inegável que, em "Savoir"/"Saber ver, a questão do acesso ao mundo persista em seus próprios termos: além da questão da miopia ser o cerne do escrito, o mundo passa de não-visto a visto pela primeira vez, ele surge da ausência e demonstra guardar algo daquilo que Gilda de Mello e Souza apontou como traço do feminino, desta maneira: "Assim saía o mundo da sua reserva distante, das suas ausências cruéis" (Cixous, 2001, p. 13). ${ }^{16}$

No entanto, esta primeira vez não é apenas um eixo de "Savoir”/“Saber ver”, ela aparece em outras obras e tem relação com a língua e com a escrita, como se escutar e escrever sempre fossem pela primeira vez. Ao ler Clarice Lispector, isso que estou chamando de "primeira vez", aparece como "antes", antes da lei, do conceito e do uso, deslocando o perto do coração selvagem da vida para perto do coração de um recém-nascido (Cf. Cixous, 2017, p.9).

Gilda de Mello e Souza também aponta que essa visão míope de Clarice Lispector impede uma visão de conjunto, assim como o desamparo próprio à visão de um recémnascido impediria a constituição de um sentido substancial. No entanto, a própria Hélène Cixous indica que a leitura fragmentária não dispensa a (re)leitura integral de uma obra, o detalhe ganhará contornos mais nítidos na própria ação de tirar e recolocar os óculos, entre um gesto e outro, aquele que vê experimentará o objeto na proximidade (leitura do fragmento) que percebe os seus detalhes mais insignificantes e no afastamento (escrita do conjunto) que cria a distância respeitosa que a leitura da diferença exige. A partir do movimento de proximidade e distância entre o sujeito e o objeto é que poderá surgir um terceiro elemento que não pertence a ninguém, a obra, a literatura. E, depois, virá a sua leitura crítica, isto é, a que depende do ato de releitura que, como o trabalho do sonho, não se faz sem bisturi e sem corte sobre as letras. Depois do ato de leitura, do corte e do gesto que resitua o fragmento, poderão vir o conceito e a teoria. Uma leitura pautada pelo ato que, como 
bem mostra a leitura que Hélène Cixous faz de Clarice Lispector, não faz o tema rivalizar com o estilo. Afinal, foi a própria Clarice quem disse, sem concessões, que "sem uma forma nada me existe" e que "a forma é que faz o conteúdo."

O leitor deste artigo certamente pôde ler em filigrana a relação entre a miopia como procedimento e as questões entre o pesquisador, o pesquisar e o seu objeto. De todo modo, gostaria de trançar de modo mais explícito alguns fios desta relação metafórica. Certamente, pode-se pensar os três objetos cortantes apreendidos a partir da leitura detalhada de "Evolução de uma miopia" - um dente de ouro, uma retirada do olhar e um amor impossível - como formas para os impasses que surgem em toda pesquisa que ser quer atenta e rigorosa. No meio do caminho surgem os ciscos, as pedras, os fracassos e a necessidade de construir desvios. Diante do problema inesperado que torna turva a proposição inicial e desequilibra a construção antecipada, o pesquisador pode construir um desvio que expulsa o corpo estranho à linha planejada ou pode fazer evoluir sua miopia, desviar-se do ideal de evidência, e buscar uma forma que inclua o impasse e ponha de luto o saber já pronto da noite anterior. Trata-se de, nessa visão a cada vez renovada da pesquisa, incluir o cisco, aprofundá-lo, ver melhor as escuridões que ele provoca e doar-lhes forma para que assim, dessas escuridões e não a despeito delas, se erga um novo dia, um novo mundo, quem sabe.

\section{Notas}

1. Agradeço a Patrick Gert Bange que discutiu e iluminou muitos pontos deste artigo que, até a sua leitura, eram opacos para mim.

2. Este artigo é parte da pesquisa fomentada pela bolsa de produtividade do CNPq, pela bolsa Cientista do Nosso Estado da FAPERJ e pela bolsa de Pós Doutorado da Capes.

3. Je suis en train de te rappeler au fin travail du rêve: il fait passer le bistouri laser invisible d'abord entre les lettres. (Cixous, 2003, p. 13) (Tradução minha)

4. Remeto o leitor à dissertação de mestrado de Jean-Claude Lucien Miroir, Clarice Lispector via Hélène Cixous: uma leitura-escritura em vis-à-vis. Nela, o autor também se dedica a pensar o modo de Cixous ler "a literatura com a literatura", enfocando outros textos e interessado em outras noções da Teoria da Literatura.

5. Lê-se nas primeiras páginas de No caminho de Swann: “[...] o odor e o sabor permanecem ainda por muito tempo, como almas, lembrando, aguardando, esperando, sobre as ruínas de tudo o mais, e suportando sem ceder, em sua gotícula impalpável, o edifício imenso da recordação" (Proust, 2006, pp. 72-73).

6. Este ensaio foi extraído e traduzido a partir do livro L'heure de Clarice Lispector, publicado em 1989.

7. A própria Cixous, em "Savoir"/ "Saber ver", explicita o caráter de invenção desta palavra: "Qual é o equivalente de inaudito? Inviso [Invu]? Não tinha ainda havido inviso. Era uma invenção. E acabava de começar" (Cixous, 2001, p. 14).

8. No encarte do original, Voiles, lê-se: "[...] et met en deuil le savoir de la nuit passé".

9. Remeto o leitor ao belo ensaio de Mireille Calle-Gruber "Saber ver ou da relação de incerteza". In: CalleGruber, M. e Mallet M-L. Travessias da escrita: leituras de Hélène Cixous e Jacques Derrida.

10. La myopie était sa faute, sa laisse, son voile natal imperceptible. Chose étrange, ele voyait qu'elle ne voyait pas, mais elle ne voyait pas bien. Chaque jour il y avait refus, mais qui pouvait dire d'où partait le refus: qui se refusait, était-ce le monde ou ele? Elle était de cette race obscure subreptice qui va désemparée devant le grand tableau du monde, tout ela journée em posture d'aveu: je ne vois pas le nom de la rue, je ne vois pas 
le visage, je ne vois pas la porte, je ne vois pas venir et c'est moi que ne vois pas ce que je devrais voir. Elle avait des yeux et elle était aveugle (Cixous, 1998, p.11).

11. [...] la science venait de vaincre l'invincible. En dix minutes ce fut fait. Fin de l'infinie. Une possibilité encore impossible il y a trois ans. [...] Jamais ne lui était venu à l'esprit qu'elle puisse changer son lot. Le sang une fois versé dans la pouissière, il ne remonte pas dans les veines. Personne n'aurait jamais contredit Eschyle. Voici le sang remonta. Elle renaquit. [...] Avant elle n'était pas une femme d'abord elle était une myope c'est-à-dire une masquée. [...] La myopie était sa vérité. (Cixous, 1998, p.15-17)

12. Em muitos momentos de sua obra Hélène Cixous indica não somente um pensamento sobre o trágico ligado ao detalhe, como o seu próprio fazer carrega dele vestígios. Lembro também que Cixous traduziu as Eumênides para encenação no Théâtre du soleil.

13. Abro um livro, a luz se faz, a língua logo começa sua narrativa, me refabrico sempre, eu mesma, com essas moléculas literárias, me digo outra vez como hoje, são seis horas da manhã sete horas talvez, escuto o sopro regular e curiosamente forte dos livros sobre minhas estantes. (Tradução minha).

14. Cf.: DERRIDA, Jacques. Gêneses, genealogias, gêneros e o gênio. Tradução: Eliane Lisboa. Lisboa, Editora Sulina, 2005.

15. Neste ponto, gostaria de remeter o leitor ao ensaio de Jacques Derrida - "A fita de máquina de escrever (Limited Ink II)", nele, a partir de Santo Agostinho e de Rosseau, o filósofo articula as cenas do roubo de cada uma das Confissões às questões que, para ele, são indissociáveis da autobiografia, como a referencialidade, a culpa, o perdão.

16. Ainsi le monde sortait de sa réserve lointaine, de ses absences cruelles (Cixous, 1998, p.15).

\section{Referências}

CALLE-GRUBER, Mireille; MALLET, Marie-Louise. Travessias da escrita: leituras de Hélène Cixous e Jacques Derrida. Tradução e prefácio: Fernanda Bernardo. Braga: Palimage Editores, 2003.

CIXOUS, Hélène. 1975. La risa de la Medusa: ensayos sobre la escritura. Prologo y traducción: Ana Mana Moix. Traducción revisada por Myriam Diaz-Diocaretz. Barcelona: Anthropos; Madrid: Comunidad de Madrid. Consejera de Educación. Direeción General de la Mujer; San Juan: Universidad de Puerto Rico, 1995.

CIXOUS, Hélène. L'heure de Clarice Lispector. Paris: des femmes, 1989.

CIXOUS, Hélène. "Savoir”. In: Voiles. Paris: Galilée, 1998.

CIXOUS, Hélène. “Saber ver”. In: Véus... à vela. Tradução: Fernanda Bernardo. Coimbra: Quarteto, 2001.

CIXOUS, Hélène. Manhattan: lettres de la préhistoire. Paris: Galilée, 2002.

CIXOUS, Hélène. Rêve je te dis. Paris: Galilée, 2003.

CIXOUS, Hélène. "Extrema fidelidade". In: LISPECTOR, Clarice. A hora da estrela: edição com manuscritos e ensaios inéditos. [concepção visual e projeto gráfico Izabel Barreto]. $1^{\text {a }}$ Ed. Rio de Janeiro: Rocco, 2017.

DERRIDA, Jacques. 2001. “A fita da máquina de escrever.” In: Papel-Máquina. Tradução: Evando Nascimento. São Paulo: Estação liberdade, 2004.

DERRIDA, Jacques. 2003. Gêneses, genealogias, gêneros e o gênio. Tradução: Eliane Lisboa. Lisboa: Editora Sulina, 2005.

ÉSQUILO. Eumênides. Estudo e tradução: Jaa Torrano. São Paulo: Iluminuras, 2018.

HOUAISS. Grande Dicionário Houaiss. Consultado online em 15/08/2020.

LISPECTOR, Clarice.1964. A legião estrangeira. São Paulo: Siciliano, 1992.

LISPECTOR, Clarice. 1984. A descoberta do mundo. Rio de Janeiro: Rocco, 1999. 
MELLO e SOUZA, Gilda. "O vertiginoso relance". In: Exercícios de leitura. São Paulo: Duas Cidades; Ed. 34, 2009.

MIROIR, Jean-Claude Lucien. Clarice Lispector via Hélène Cixous: uma leitura-escritura em vis-à-vis. Brasília: UnB, 2009. Dissertação de Mestrado.

PROUST, Marcel. 1913. No caminho de Swann. Tradução: Mario Quintana. $3^{a}$ ed. São Paulo: Globo, 2006.

\section{Correspondência}

Flavia Trocoli: Professora Associada da Faculdade de Letras da UFRJ. Doutora em Teoria e História Literária pela UNICAMP. Membro-fundador do Centro de Pesquisas Outrarte - a psicanálise entre a ciência e a arte (IEL/UNICAMP). Autora do livro "A inútil paixão do ser: figurações do narrador moderno" e de ensaios em torno de Clarice Lispector, Virginia Woolf, Marcel Proust, Marguerite Duras, Hélène Cixous e Jacques Derrida. Co-organizadora dos livros: "Um retorno a Freud", "Giros da interpretação" e "Teoria Literária e suas fronteiras". Traduziu com Carla Rodrigues "Demorar: Maurice Blanchot", de Jacques Derrida.

E-mail: flaviatrocoli@letras.ufrj.br

Texto publicado em Currículo sem Fronteiras com autorização dos autores. 